\title{
Peran Kepemimpinan Tokoh Informal terhadap Kemandirian Pemuda Sekitar Hutan di Kabupaten Bogor
}

\author{
Yoyon Haryanto', Suyadi $^{2}$ \\ Politeknik Pembangunan Pertanian Bogor ${ }^{1}$, Balai Diklat Kehutanan Rumpin-Bogor ${ }^{2}$ \\ yoyonharyanto@gmail.com ${ }^{1}$, suyadi.wsd@gmail.com ${ }^{2}$
}

\begin{abstract}
Youth around the forest in general is still very trusting, submissive and obedient to their informal leader. Independence of youth around the forest can be measured from the power strain, competitiveness and sanding. The purpose of this study was to analyze the factors that influence the leadership role of informal leaders, youth independence around the forest, and the leadership role of informal leaders on youth independence around the forest. The research was conducted from October to November 2020, located in the village of Pasir Madang, Sukajaya Subdistrict, Bogor Regency with a sample size of 50 youth. Data were analyzed using path analysis (path analysys). The results of this study are the factors that directly affect the leadership role of informal figures are the individual factors of informal figures, the independence factor of youth around the forest is influenced by the leadership role of informal figures and individual factors of informal figures, and the leadership role of informal figures significantly affects the independence of youth around the forest. Extension support by the government tarhadap informal leaders need to be improved, so that the informal leaders can be more active, innovative, and also care about the community.
\end{abstract}

Keywords: self-reliance; leadership; informal; forest's area.

\begin{abstract}
Abstrak
Pemuda di sekitar hutan pada umumnya masih sangat percaya, patuh dan taat pada pemimpin informal mereka. Kemandirian pemuda sekitar hutan dapat diukur dari daya saring, daya saing dan daya sanding. Tujuan penelitian ini yaitu menganalisis faktor-faktor yang mempengaruhi peran kepemimpinan tokoh informal, kemandirian pemuda sekitar hutan, dan pengaruh peran kepemimpinan tokoh informal terhadap kemandirian pemuda sekitar hutan. Penelitian dilaksanakan bulan Oktober sampai Nopember 2020 yang berlokasi di Desa Pasir Madang, Kecamatan Sukajaya, Kabupaten Bogor dengan jumlah sampel pemuda sebanyak 50 orang. Data yang diperoleh dianalisis menggunakan analisis jalur (path analysis). Hasil penelitian ini adalah (1) faktor-faktor yang mempengaruhi langsung terhadap peran kepemimpinan tokoh informal adalah faktor individu tokoh informal, (2) faktor-faktor yang mempengaruhi secara langsung atau tidak langsung terhadap kemandirian pemuda sekitar hutan adalah peran kepemimpinan tokoh informal dan faktor individu tokoh informal, (3) Peran kepemimpinan tokoh informal berpengaruh nyata terhadap kemandirian pemuda sekitar hutan. Dukungan penyuluhan oleh pihak pemerintah tarhadap tokoh informal perlu ditingkatkan, sehingga tokoh informal bisa lebih aktif, inovatif, dan juga peduli terhadap masyarakat.
\end{abstract}

Kata Kunci: kemandirian; kepemimpinan; informal; sekitar hutan. 


\section{A. PENDAhuluan}

Karakteristik masyarakat sekitar hutan pada umumnya adalah paternalistik. Hal ini dapat dicirikan dari watak anggota masyarakat. Secara umum, mereka masih sangat patuh dan taat kepada pemimpin mereka. Patuh dan taat terhadap orang-orang yang ditokohkan baik secara formal maupun informal. Tokoh informal di lingkungan masyarakat yang paternalistik mempunyai peran penting dalam pengembangan manusia. Hal ini selaras dengan Riyanto et al. (2011) yang menyatakan bahwa tokoh masyarakat sekitar hutan kemiri dapat memainkan peranan penting dalam memotivasi masyarakat atau petani sekitar hutan untuk melestarikan hutan.

Tokoh informal di tengah-tengah komunitas masyarakat desa yang paternalistik, mempunyai potensi besar untuk dapat memainkan peran kepemimpinannya karena memiliki sifat keteladanan. Hal ini mengingat bahwa konsep dasar dari kepemimpinan adalah kemampuan mempengaruhi orang lain untuk menjadi pengikutnya. Seperti yang dikemukakan oleh Soekanto (2013) bahwa kepemimpinan merupakan kemampuan untuk memimpin dan memberikan pengaruh kepada orang lain sehingga orang lain tersebut bertingkah laku sebagaimana dikehendaki oleh pemimpin tersebut.

Pemuda di sekitar hutan merupakan generasi yang diharapkan dapat menjaga dan melanjutkan kelangsungan budaya dan kelestarian sumber daya alam termasuk sumber daya hutan. Pemuda diidentikkan dengan potensi yang ada untuk regenerasi sumber daya manusia dan sumber insani bagi pembangunan karena pemuda sebagai harapan bangsa dapat diartikan bahwa siapa yang menguasai pemuda akan menguasai masa depan. Menurut Setiawan et al. (2015) bahwa pemuda merupakan kunci kemajuan bangsa dan sumber daya sangat penting dan strategis dalam pembangunan karena memiliki pengembangan potensi dalam dirinya.

Pengembangan potensi ini dapat mencerminkan terwujudnya kemandirian pada pemuda. Kemandirian pemuda merupakan modal awal untuk dapat memainkan peran selanjutnya sebagai generasi penerus pembangunan yang berkualitas. Berkaitan dengan kemandirian pemuda sekitar hutan, Sumardjo (1999) menjelaskan tentang konsep kemandirian petani adalah petani yang secara utuh mampu memilih dan mengarahkan kegiatan usahataninyasesuai dengan kehendaknya sendiri, yang diyakini paling tinggi manfaatnya, tetapi bukan berarti sikap menutup dirimelainkan dengan rendah hati menerima situasi masyarakat dan aturanaturan yang ada di dalamnya.

Berdasarkan fenomena tersebut tentunya menjadi penting untuk melakukan kajian tentang peran kepemimpinan tokoh informal terhadap kemandirian pemuda sekitar hutan. Tujuan penelitian ini adalah menganalisis faktor-faktor yang mempengaruhi peran kepemimpinan tokoh informal, menganalisis faktor-faktor yang mempengaruhi kemandirian pemuda sekitar hutan, dan menganalisis pengaruh peran kepemimpinan tokoh informal terhadap kemandirian pemuda sekitar hutan.

\section{B. PELAKSANAAN DAN METODE}

Penelitian dilaksanakan selama empat bulan yaitu mulai Agustus sampai dengan Nopember 2020. Lokasi di Desa Pasir Madang Kecamatan Sukajaya Kabupaten Bogor Provinsi Jawa Barat. Dasar pertimbangan pemilihan lokasi penelitian ini adalah wilayah desa Pasir Madang berada di 
sekitar Kawasan Taman Nasional Gunung Halimun Salak yang merupakan unit Kesatuan Pengelolaan Hutan (KPH) Konservasi.

Metode yang digunakan dalam penelitian ini adalah metode survey dengan menyebarkan quisioner dan juga wawancara. Penelitian ini dilakukan untuk menguji hipotesis. Data yang terkumpul selanjutnya dilakukan pengolahan dan analisis dengan menggunkan path analysis.

Populasi dalam penelitian ini adalah masyarakat pemuda di sekitar kawasan hutan konservasi yang dikelola dengan sistem Kesatuan Pengelolaan Hutan (KPH) yaitu Kawasan Taman Nasional Gunung Halimun Salak. Di Desa Pasir Madang terdapat lembaga pendidikan tingkat SMA yaitu SMK Pesona Dywantara yang dikelola atau dibangun atas prakarsa dari para tokoh masyarakat dalam rangka menampung anakanak usia sekolah atau pelajar dan pemuda di Desa Pasir Madang pada khususnya dan juga desa-desa sekitarnya. Mengingat semua populasi dijadikan sampel maka penetapan sampel dilakukan secara sensus. Jumlah populasi sekaligus sampel penelitian yaitu pemuda pelajar SMK Pesona Dywantara kelas 10 dan 11 adalah sebanyak 50 orang yang terdiri dari laki-laki 17 orang dan perempuan 33 orang.

\section{HASIL DAN PEMBAHASAN}

\section{Faktor Individu Pemuda}

Faktor individu pemuda yang diamati dalam penelitian ini adalah tingkat kepercayaan kepada tokoh informal, tingkat kepatuhan kepada norma dan tokoh informal, dan tingkat pemanfaatan informasi khususnya tentang kehutanan. Hasil penelitian menunjukkan bahwa faktor individu pemuda tergolong tinggi ada pada tingkat kepercayaan kepada tokoh informal.
Bukti kepercayaan responden kepada tokoh informal ini ditunjukkan pada saat pengambilan keputusan. Keputusan yang diambil oleh tokoh masyarakat, responden senantiasa akan mengakui, menjunjung tinggi dan mengikutinya. Bukti lain, responden memberikan kewenangan kepada tokoh informal untuk mewakili dalam pertemuanpertemuan yang diselenggarakan oleh pemerintah atau pihak-pihak lain.

Tingkat kepatuhan responden kepada norma dan tokoh informal adalah sangat tinggi yaitu sebanyak $100 \%$ responden tergolong cukup patuh dan sangat patuh. Demikian juga dengan tingkat pemanfaatan informasi. Responden menunjukan bahwa $100 \%$ tingkat pemanfaatan informasi relatif tinggi dan bermanfaat. Dengan demikian, berdasarkan hasil pengukuran tersebut tentunya akan memudahkan dalam penyusunan strategi pembangunan di bidang kehutanan khususnya yang ada di wilayah Kabupaten Bogor dengan meningkatkan keterlibatan tokoh informal, hal ini mengingat bahwa responden menunjukkan tingkat kepercayaan, tingkat kepatuhan dan tingkat pemanfaatan informasi yang tinggi.

\section{Faktor Individu Tokoh Informal}

Hasil penelitian ini menunjukkan bahwa faktor individu tokoh informal tergolong tinggi yaitu rata-rata adalah $98 \%$ yang berarti tokoh informal memiliki keperibadian yang dapat dicontoh dan ditiru baik perilaku, tata krama dan kepemimpinannya. Hal ini selaras dengan kondisi tokoh informal yang ada di wilayah tersebut yang tergolong aktif, inovatif, dan peduli terhadap masyarakatnya serta sesuai dengan status sosialnya.

\section{Peran Kepemimpinan Tokoh Informal}

Peran kepemimpinan tokoh informal yang dibahas dalam penelitian ini adalah peran interpersonal, peran informasional dan 
peran pengambilan keputusan. Hasil penelitian ini menunjukkan bahwa peran kepemimpinan tokoh informal tergolong tinggi dengan nilai rata-rata respon dari responden menunjukkan $95 \%$ yang berarti responden menjawab dengan kehadiran tokoh informal memiliki tempat untuk menyampaikan berbagai permasalahan yang dihadapi oleh masayarakat dan memiliki kepempinan yang tergolong berperan baik secara interpersonal, informasional atau pengambilan keputusan.

\section{Kemandirian Pemuda Sekitar Hutan}

Kemandirian pemuda sekitar hutan yang dibahas dalam penelitian ini adalah daya saring, daya saing dan daya sanding. Hasil penelitian menegaskan bahwa kemandirian pemuda sekitar hutan tergolong tinggi yaitu rata-rata adalah 96\%. Penilaian responden terhadap kemandirian pemuda sekitar hutan tergolong mandiri baik daya saring, daya saing, maupun daya sanding sebagai akibat dari peran kepemimpinan tokoh informal.

\section{Faktor-faktor yang Mempengaruhi Peran Kepemimpinan Tokoh Informal}

Berdasarkan analisis Jalur (Path Analisys) menggunakan SPSS, diperoleh bahwa Faktor individu pemuda (X1) dengan indikator terdiri dari tingkat kepercayaan, tingkat kepatuhan dan tingkat pemanfaatan informasi, tidak berpengaruh langsung terhadap peran kepemimpinan tokoh informal (Y1). Mengukur tingkat kekuatan hubungan antar variabel, digunakan uji regresi dalam bagian dari analisis jalur. Uji ini dimaksudkan guna mengetahui apakah variabel bebas mempunyai pengaruh langsung atau tidak langsung terhadap variabel tidak bebas. Hasil uji regresi, secara simultan variabel faktor individu pemuda dan faktor individu tokoh informal memiliki kontribusi sebesar 12,1 persen dalam menjelaskan perubahan yang terjadi pada variabel Peran Kepemimpinan Tokoh Informal sedangkan sisanya sebesar 87,9 persen dijelaskan oleh variabel lain di luar model (Tabel 1).

Tabel 1. Analisis signifikansi variabel yang berpengaruh terhadap peran kepemimpinan tokoh informal

\begin{tabular}{lcc}
\hline \multicolumn{1}{c}{ Variabel } & $\begin{array}{c}\text { Koefisi } \\
\text { en } \\
\text { regresi }\end{array}$ & Sign \\
\hline Konstan & & 0.001 \\
Faktor Individu Pemuda $\left(\mathrm{X}_{1}\right)$ & -0.229 & 0.107 \\
Faktor Individu Tokoh & 0.310 & 0.031 \\
Informal $\left(\mathrm{X}_{2}\right)$ & & \\
Nilai R : 0.348 & & \\
Nilai Koefisian Determinasi (R2) : 0.121 & \\
\hline
\end{tabular}

Pada Coefficients, uji t/parsial menunjukkan bahwa variabel faktor individu pemuda secara statistik tidak memiliki pengaruh yang signifikan terhadap variabel peran kepemimpinan tokoh informal. Nilai signifikan hasil perolehan yaitu lebih besar dari Alpha 5\% yaitu 0,107. Sedangkan variabel faktor individu tokoh informal secara statistik memiliki pengaruh yang signifikan terhadap variabel peran kepemimpinan tokoh informal. Mengingat faktor individu pemuda tidak signifikan berpengaruh terhadap variabel peran kepemimpinan tokoh informal maka variabel faktor individu pemuda tersebut dieliminasi dari model. Persamaan strukturalnya menjadi seperti berikut: $\mathrm{Y}_{1}=$ $0,310 X_{2}+\epsilon 1$

Berdasarkan hasil analisa diatas, maka hipotesis bahwa faktor individu pemuda berpengaruh nyata terhadap peran kepemimpinan tokoh informal adalah ditolak. Hal ini mengingat bahwa dalam kenyataannya dilapangan ternyata faktor individu pemuda tidak mempunyai pengaruh langsung yang signifikan terhadap peran kepemimpinan tokoh informal. Faktor individu pemuda yang diantaranya meliputi indikator tingkat 
kepercayaan, tingkat kepatuhan dan tingkat pemanfaatan informasi walaupun ditingkatkan maka hal tersebut tidak berpengaruh langsung secara signifikan terhadap meningkatnya peran kepemimpinan tokoh informal secara simultan baik dalam hal peran-perannya yang dapat mempengaruhi orang lain.

Hipotesis berikutnya tentang faktor individu tokoh informal berpengaruh nyata terhadap peran kepemimpinan tokoh informal adalah diterima. Hasil analisa membuktikan bahwa faktor individu tokoh informal mempunyai pengaruh langsung yang signifikan terhadap peran kepemimpinan tokoh informal. Faktor individu tokoh informal yang meliputi indikator tingkat keaktifan, tingkat keinovatifan, tingkat kepedulian, dan status sosial tokoh informal bila ditingkatkan akan memberikan pengaruh langsung terhadap meningkatnya peran kepemimpinan tokoh informal. Semakin aktif, inovatif, peduli, dan status sosial yang tinggi seorang tokoh informal maka peran kepemimpinan yang ditampilkan juga semakin meningkat. Peningkatan peran kepemimpinan tokoh informal tersebut dapat dilihat dari indikator peran yang mampu menjadikan ketokohannya dapat memberikan rasa aman, nyaman dan bekerja bersama.

Hasil analisa jalur terhadap variabelvariabel bebas yaitu faktor individu pemuda dan faktor individu tokoh informal terhadap variabel antara yaitu peran kepemimpinan tokoh informal diperoleh model sebagai seperti pada Gambar 1.

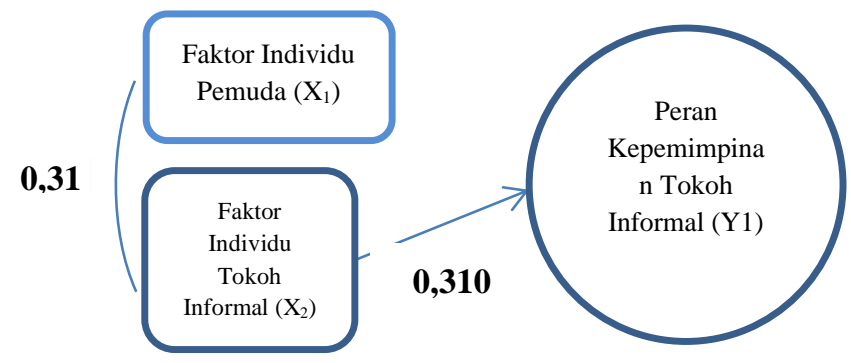

Gambar 1. Model pengaruh langsung variabel

\section{Faktor-faktor yang mempengaruhi kemandirian pemuda sekitar hutan}

Uji regresi pada struktur kedua dilakukan pada variabel bebas dan variabel antara terhadap variabel tidak bebas. Variabel bebas meliputi faktor individu pemuda dan faktor individu tokoh informal. Variavel antara yaitu peran kepemimpinan tokoh informal dan variabel tidak bebas yaitu kemandirian pemuda sekitar hutan.

Hasil uji memprlihatkan kesimultanan variabel faktor individu pemuda, faktor individu tokoh informal dan peran kepemimpinan tokoh informal memiliki kontribusi sebesar 68,8 persen dalam menjelaskan perubahan yang terjadi pada variabel kemandirian pemuda sekitar hutan. Sedangkan sisanya sebesar 31,2 persen dijelaskan oleh variabel lain di luar model.

Tabel 2. Analisis signifikansi variabel yang berpengaruh terhadap Kemandirian pemuda sekitar hutan

\begin{tabular}{|c|c|c|}
\hline Variabel & Koefisien regresi & Sign \\
\hline Konstan & & 0.001 \\
\hline $\begin{array}{ll}\text { Faktor } & \text { Individu } \\
\text { Pemuda }\left(\mathrm{X}_{1}\right) & \end{array}$ & -0.229 & 0.107 \\
\hline $\begin{array}{l}\text { Faktor Individu Tokoh } \\
\text { Informal }\left(\mathrm{X}_{2}\right) \\
\text { Nilai } \mathrm{R}: 0.348\end{array}$ & 0.310 & 0.031 \\
\hline \multicolumn{3}{|c|}{ Nilai Koefisian Determinasi (R2) : 0.121} \\
\hline
\end{tabular}

Pada Coefficients, uji t/parsial terlihat faktor individu pemuda dan faktor individu tokoh informal secara statistik tidak memiliki pengaruh yang signifikan terhadap variabel kemandirian pemuda sekitar hutan. Hal ini ditunjukkan oleh nilai Signifikan lebih besar dari Alpha 5\% yaitu masing-masing 0,788 dan 0,544 . Sedangkan variabel antara yaitu peran kepemimpinan tokoh informal secara statistik memiliki pengaruh yang signifikan terhadap variabel kemandirian pemuda sekitar hutan. Pengaruh yang signifikan ini 
terlihat dari nilai Sig. sebesar $0,000<$ Alpha $5 \%$. Dari ketiga variabel yang dilakukan uji regresi terhadap variabel tidak bebas yaitu kemandirin pemuda sekitar hutan, ternyata yang memberikan pengaruh langsung adalah variabel antara yaitu peran kepemimpinan tokoh informal. Sedangkan kedua variabel bebas yaitu faktor individu pemuda dan faktor individu tokoh informal tidak memberikan pengaruh langsung terhadap variabel kemandirian pemuda sekitar hutan. Berdasarkan hal tersebut, maka persamaan strukturalnya menjadi seperti pada Gambar 2 .



Gambar 2. Model pengaruh langsung dan tidak langsung variabel

Berdasarkan hasil analisa diatas, maka hipotesis bahwa faktor individu pemuda berpengaruh nyata terhadap kemandirian pemuda sekitar hutan adalah ditolak. Hal ini mengingat bahwa dalam kenyataannya dilapangan ternyata faktor individu pemuda tidak mempunyai pengaruh langsung yang signifikan terhadap kemandirian pemuda sekitar hutan. Faktor individu pemuda yang diantaranya meliputi indikator tingkat kepercayaan, tingkat kepatuhan dan tingkat pemanfaatan informasi walaupun ditingkatkan maka hal tersebut tidak berpengaruh langsung secara signifikan terhadap meningkatnya kemandirian pemuda sekitar hutan secara simultan baik daya saring, daya saing dan daya sanding.

Hipotesis berikutnya tentang faktor individu tokoh informal berpengaruh nyata terhadap kemandirian pemuda sekitar hutan juga ditolak. Hasil analisa membuktikan bahwa faktor individu tokoh informal tidak mempunyai pengaruh langsung yang signifikan terhadap kemandirian pemuda sekitar hutan. Faktor individu tokoh informal yang meliputi indikator tingkat keaktifan, tingkat keinovatifan, tingkat kepedulian, dan status sosial tokoh informal bila ditingkatkan tidak akan memberikan pengaruh langsung terhadap meningkatnya kemandirian pemuda sekitar hutan. Namun demikian faktor individu tokoh informal mempunyai pengaruh tidak langsung terhadap kemandirian pemuda sekitar hutan yaitu melalui varaiabel antara peran kepemimpinan tokoh informal. Disini mengandung arti bahwa bila faktor individu tokoh informal yang meliputi tingkat keaktifan,tingkat keinovatifan, tingkat kepedulian dan status sosial tokoh informal ditingkatkan maka peran kepemimpinan tokoh informal yaitu peran interpersonal, peran informasional, dan peran pengambilan keputusan akan meningkat dan selanjutnya juga berpengaruh pada meningkatnya kemandirian pemuda sekitar hutan yaitu daya saring, daya saing dan daya sanding.

Hipotesis bahwa peran kepemimpinan tokoh informal berpengaruh nyata terhadap kemandirian pemuda sekitar hutan adalah diterima. Hasil analisa membuktikan bahwa peran kepemimpinan tokoh informal mempunyai pengaruh langsung yang signifikan terhadap kemandirian pemuda sekitar hutan. Peran kepemimpinan tokoh informal yang meliputi indikator peran interpersonal, peran informasional, dan peran pengambilan keputusan bila ditingkatkan akan memberikan pengaruh langsung terhadap meningkatnya kemandirian pemuda sekitar hutan baik berupa daya saring, daya saing, maupun daya sanding secara simultan. Temuan bahwa peran kepemimpinan tokoh informal berpengaruh nyata terhadap 
kemandirian pemuda sekitar hutan adalah mendukung hasil penelitian Haryanto (2018); Kahar (2008); dan Raharjo (2006) bahwa kepemimpinan mempunyai pengaruh langsung terhadap perubahan organisasi, karena memegang peran kunci dalam mengimplementasikan strategi organisasi.

Temuan ini juga mendukung hasil penelitian Brahmasari (2013); Apriani, (2009); Kiswanto (2010); dan Potu (2013) bahwa kepemimpinan mempunyai hubungan yang kuat terhadap efektifitas kinerja karyawan. Temuan ini tidak selaras dengan hasil penelitian Posuma (2013); dan Munparidi (2012) yang menyatakan bahwa kepemimpinan tidak mempunyai pengaruh yang nyata terhadap kinerja karyawan. Temuan ini juga tidak selaras dengan hasil penelitian Liow (2015) yang menyatakan bahwa peranan pemimpin informal belum efektif terhadap partisipasi masyarakat.

Hasil temuan tentang faktor-faktor yang mempengaruhi kemandirian pemuda sekitar hutan yaitu faktor individu tokoh informal dan Peran kepemimpinan tokoh informal. Faktor tersbut berpengaruh nyata terhadap kemandirian pemuda sekitar hutan baik secara langsung atau tidak langsung. Temuan ini mendukung hasil penelitian Ristianasari (2013) yang menjelaskan tentang faktorfaktor yang mempunyai hubungan dengan kamandirian masyarakat meliputi karakteristik sosio-demografi, interaksi dan akses, serta pendekatan program pemberdayaan.

\section{PENUTUP}

\section{Simpulan}

Faktor-faktor yang mempengaruhi langsung terhadap peran kepemimpinan tokoh informal adalah faktor individu tokoh informal yang meliputi tingkat keaktifan, tingkat keinovatifan, tingkat kepedulian dan status sosial tokoh informal. Faktor-faktor yang mempengaruhi secara langsung atau tidak langsung terhadap kemandirian pemuda sekitar hutan adalah peran kepemimpinan tokoh informal dan faktor individu tokoh informal. Peran kepemimpinan tokoh informal berpengaruh langsung terhadap kemandirian pemuda sekitar hutan, sedangkan faktor individu tokoh informal berpengaruh tidak langsung terhadap kemandirian pemuda sekitar hutan yaitu terlebih dahulu harus melalui peran kepemimpinan tokoh informal.

Peran kepemimpinan tokoh informal berpengaruh nyata terhadap kemandirian pemuda sekitar hutan. Pengaruh ini menunjukkan adanya hubungan positif yang kuat antara kedua variabel tersebut. Jika peran kepemimpinan tokoh informal ditingkatkan, maka secara langsung akan terjadi peningkatan kemandirian pemuda sekitar hutan.

\section{Ucapan Terima Kasih}

Kami sampaikan terima kasih kepada pihak yang telah membantu kegiatan penelitian dan pemberdayaan masyarakat terutama pemuda tani hutan di Desa Pasir Madang. Selain itu ucapan juga disampaikan kepada Kementerian Pertanian dan Kementerian Kehutanan dan Lingkungan Hidup yang telah bersinergi dalam kegiatan pemberdayaan tersebut.

\section{DAFTAR PUSTAKA}

Apriani. (2009). Pengaruh Kompetensi, Motivasi, dan Kepemimpinan terhadap Efektivitas Kerja. Ilmu Administrasi dan Organisasi, 16(1), 13-17.

Brahmasari, I. (2013). Pengaruh Motivasi Kerja, Kepemimpinan dan Budaya Organisasi Terhadap Kepuasan Kerja Karyawan serta Dampaknya pada Kinerja Perusahaan (Studi kasus pada PT. Pei Hai International Wiratama 
Indonesia). Manajemen Dan Kewirausahaan, 2(124-135).

Haryanto, Y. (2018). Penguatan Kapasitas dan Kemandirian Tokoh Petani Maju sebagai Penyuluh Swadaya. IPB.

Kahar Irawaty A. (2008). Konsep Kepemimpinan dalam Perubahan Organisasi (Organizational Change) pada Perpustakaan Perguruan Tinggi. Studi Perpustakaan dan Informasi, 4(1), 21-27.

Kiswanto, M. (2010). engaruh Kepemimpinan Dan Komunikasi Terhadap Kinerja Karyawan Kaltim Pos Samarinda. Eksis, 6(1), 1267-1439.

Liow Michael R, L. A. dan P. W. (2015). Peranan Pemimpin Informal dalam Meningkatkan Partisipasi Masyarakat dalam Pembangungan di Desa Malola. JIAP, 31(1), 1-9.

Munparidi. (2012). Pengaruh Kepemimpinan, Motivasi, Pelatihan, Dan Lingkungan Kerja Terhadap Kinerja Karyawan Pada Perusahaan Daerah Air Minum Tirta Musi Kota Palembang. Orasi Bisnis, 7, 47-54.

Posuma, C. O. (2013). Kompetensi, Kompensasi, Dan Kepemimpinan Pengaruhnya Terhadap Kinerja Karyawan Pada Rumah Sakit Ratumbuysang Manado. EMBA, 1(4), 646-656.

Potu, A. (2013). Kepemimpinan, Motivasi, Dan Lingkungan Kerja Pengaruhnya Terhadap Kinerja Karyawan Pada Kanwil Ditjen Kekayaan Negara Suluttenggo Dan Maluku Utara Di Manado. EMBA, 1(4), 1208-1218.

Raharjo Susilo, N. D. (2006). Analisis Pengaruh Gaya Kepemimpinan Terhadap Kepuasan Kerja, Komitmen
Organisasi Dan Kinerja Karyawan (Studi Empiris Pada Departemen Agama Kabupaten Kendal Dan Departemen Agama Kota Semarang. Studi Manajemen \& Organisasi, 3(2), 69-81.

Ristianasari, M. P. dan G. D. S. (2013). Dampak Program Pemberdayaan Model Desa Konservasi Terhadap Kemandirian Masyarakat: Kasus di Taman Nasional Bukit Barisan Selatan Lampung. Jurnal Penelitian Sosial dan Ekonomi Kehutanan, 10(3), 173-185.

Riyanto Suprayitno, A., Sumardjo, S., S. Gani, D., \& Ginting Sugihen, B. (2011). Model Peningkatan Partisipasi Petani Sekitar Hutan Dalam Pengelolaan Hutan Kemiri Rakyat: Kasus Pengelolaan Hutan Kemiri Kawasan Pegunungan Bulusaraung Kabupaten Maros Provinsi Sulawesi Selatan. Jurnal Penelitian Sosial dan Ekonomi Kehutanan, 8(3), 176-195. https://doi.org/10.20886/jsek.2011.8.3. 176-195

Setiawan, I., Sumardjo, S., Satria, A., \& Tjitropranoto, P. (2015). Strategi Pengembangan Kemandirian Pelaku Muda Agribisnis " Brain Gain Actors" di Jawa Barat. MIMBAR, Jurnal Sosial dan Pembangunan, 31(2), 409. https://doi.org/10.29313/mimbar.v31i2. 1491

Soekanto. (2013). Sosiologi Suatu Pengantar. Jakarta: Rajawali Pers.

Sumardjo. (1999). Transformasi model penyuluhan pertanian menuju pengembangan kemandirian petani (Kasus di Propinsi Jawa Barat) [disertasi]. 1-372. 